\title{
Enhancement of crystal induced neutrophil responses by opsonisation of calcium pyrophosphate dihydrate crystals
}

\author{
Helen M Burt, John K Jackson
}

\begin{abstract}
Objectives-Little is known about the effect on crystal induced neutrophil responses of the opsonisation of calcium pyrophosphate dihydrate (CPPD) (triclinic) crystals with components of serum and plasma. The purpose of this study was to determine the effects of precoating CPPD crystals with plasma, serum, complement depleted serum, and IgG on a full range of crystal induced neutrophil responses (calcium mobilisation, chemiluminescence, superoxide anion production, non-cytolytic lysosomal enzyme release, and leukotriene synthesis).
\end{abstract}

Methods-Crystals were precoated with IgG, serum, plasma, or complement depleted serum (heated at $56^{\circ} \mathrm{C}$ ), incubated with neutrophils and the responses monitored with time. Measurement of the extent of neutrophil association with crystals was based on monitoring the decrease in fluorescence intensity of supernatants when crystals and diphenylhexatriene labelled neutrophils were allowed to settle under gravity.

Results-Precoating CPPD crystals with IgG, plasma, and serum significantly enhanced chemiluminescence, superoxide anion generation, increases in cytosolic free calcium levels, and non-cytolytic lysosomal enzyme release by neutrophils compared with uncoated CPPD crystals. The enhancement of neutrophil responses by crystals coated with complement depleted serum was less pronounced. The increased neutrophil responses induced by CPPD crystals coated with IgG might have been due to the observed increase in the association of IgG coated crystals with neutrophils.

Conclusions-These data show that there is a marked potentiation of all neutrophil responses to IgG, plasma, and serum coated CPPD crystals. It is suggested that the adsorption of synovial fluid proteins, including IgG and C3b, to CPPD crystals in vivo, results in the opsonised crystals becoming a potent neutrophil stimulant and inflammatory agent.

(Ann Rheum Dis 1993; 52: 599-607)

Calcium pyrophosphate dihydrate (CPPD) crystals in the synovial fluid of joints produce the inflammatory reaction of acute pseudo- gout. This inflammation is now established as being derived primarily from the interaction of polymorphonuclear leucocytes or neutrophils with CPPD crystals. Previous in vitro studies have shown that neutrophils stimulated by synthetic CPPD crystals are slower to reach maximum response and produce less extensive neutrophil responses than neutrophils stimulated by synthetic monosodium urate monohydrate (MSUM) crystals. ${ }^{1-5}$

Crystals of CPPD and MSUM have been shown to adsorb protein components from plasma and synovial fluid (an ultrafiltrate of plasma), ${ }^{6-9}$ and these adsorbed proteins are believed to exert a modulatory effect on the interaction of crystals and neutrophils. Indeed, crystals that have been precoated with synovial fluid or plasma components before incubation with neutrophils in vitro more closely model in vivo crystal-neutrophil interactions. Crystals of CPPD have been shown to adsorb small amounts of IgG, and CPPD crystals precoated with IgG alone produced no significant effects on neutrophil superoxide anion production compared with uncoated crystals. ${ }^{2}$ Crystals of MSUM, on the other hand, adsorbed greater amounts of IgG leading to a significantly enhanced ability of the IgG coated crystals to stimulate neutrophils, with increased superoxide anion production and lysosomal enzyme release. $^{210-12}$ The effects on crystal induced neutrophil responses of precoating crystals with plasma or serum have been studied extensively for MSUM but not for CPPD. Terkeltaub and coworkers showed that precoating MSUM with plasma inhibited chemiluminescence, superoxide generation, cytolysis, and phagocytosis, ${ }^{13} 14$ whereas Abramson et $a l^{11}$ reported that MSUM induced neutrophil superoxide generation was inhibited by precoating the crystals with serum but not plasma. Kozin et $a l^{10}$ showed an inhibition of cytolysis but an enhancement of lysosomal enzyme release when MSUM crystals were coated with serum.

In this work we have investigated a full range of neutrophil responses to CPPD crystals, the effect of opsonisation with IgG, and the effect of precoating CPPD crystals with plasma or serum. Although published reports suggest that CPPD crystals are relatively weak stimulators of neutrophil responses compared with MSUM, ${ }^{124}$ we have shown that CPPD crystals are strong activators of neutrophil responses. Also, contrary to the effects of plasma opsonisation of MSUM, which has been shown in general to inhibit neutrophil 
responses, we have shown that opsonisation of CPPD crystals with plasma or serum significantly enhanced CPPD induced neutrophil responses.

\section{Materials and methods}

BUFFER

Hanks's buffered salt solution (HBSS), $\mathrm{pH} 7 \cdot 4$, was used throughout.

PREPARATION AND CHARACTERISATION OF CRYSTALS

Crystals of CPPD (triclinic) were prepared and were characterised using $x$ ray diffraction and differential scanning calorimetry as previously described, ${ }^{15}$ and were used unheated in all studies. $x$ Ray diffraction patterns showed all d spacings characteristic of triclinic CPPD crystals and there was no evidence of any additional peaks due to other crystalline phases such as monoclinic CPPD. Two endothermic peaks on the differential scanning calorimetry thermograms corresponding to the loss of two moles of water from the solid indicated the presence of the dihydrate. ${ }^{15}$ The size distribution of the crystals was approximately $33 \%$ less than $10 \mu \mathrm{m}, 58 \%$ between 10 and $20 \mu \mathrm{m}$, and $9 \%$ greater than $20 \mu \mathrm{m}$. Crystals of CPPD were washed in HBSS using the same procedure as for precoating crystals with proteins, and were tested for the presence of pyrogens using the Limulus amebocyte assay (Sigma kit No 210-A1-E-Toxate). The CPPD samples were free of pyrogens.

NEUTROPHIL PREPARATION

Neutrophils were prepared by dextran sedimentation and Ficoll Paque (Pharmacia) density centrifugation. The pellets were washed free of erythrocytes by 20 seconds of hypotonic shock using distilled water followed by the restoration of tonicity with $0.6 \mathrm{M} \mathrm{NaCl}$. Neutrophils were resuspended in HBSS, stored on ice, and used for experiments within three hours. Neutrophils always represented greater than $90 \%$ of the suspension, and cell viability, as estimated by trypan blue exclusion, was greater than $95 \%$.

INCORPORATION OF FURA 2AM OR DIPHENYLHEXATRIENE INTO NEUTROPHILS Cells $\left(5 \times 10^{6}\right.$ cells $\left./ \mathrm{ml}\right)$ in either $1 \mu \mathrm{M}$ fura 2AM (Sigma Chemical) or $1 \mu \mathrm{M}$ diphenylhexatriene (Sigma) in HBSS were incubated at room temperature for 30 minutes, centrifuged at $400 \mathrm{~g}$ for six minutes, washed, and resuspended in HBSS.

CYTOSOLIC CALCIUM DETERMINATIONS

All determinations were made at $37^{\circ} \mathrm{C}$. Fluorescence emission from $1.5 \mathrm{ml}$ fura 2 loaded cells in the presence or absence of crystals was recorded continuously by excitation at $340 \mathrm{~nm}$ and emission at $500 \mathrm{~nm}$. Increases in the values of the fluorescence intensities (F) from fura 2 loaded neutrophils due to light scattering effects from crystals were corrected by subtraction of the scatter intensity $\left(F_{\text {scat }}\right)$. Cytosolic free calcium concentrations $\left[\mathrm{Ca}^{2+}\right]_{\mathrm{i}}$ were determined using the following equation

$$
\left[\mathrm{Ca}^{2+}\right]_{\mathrm{i}}=\mathrm{Kd} \frac{\left(\mathrm{F}-\mathrm{F}_{\min }\right)}{\left(\mathrm{F}_{\max }-\mathrm{F}\right)}
$$

where $F_{\max }$ and $F_{\min }$ are the (scatter corrected) fluorescence intensities at maximum $(0.02 \%$ Triton X-100) and minimum (50 mM EGTA) calcium concentrations and $\mathrm{Kd}$ is the dissociation of fura 2 with $\mathrm{Ca}^{2+}$ and is equal to $224 \mathrm{nmol} / 1 .{ }^{16}$ To measure light scattering intensities produced by adding crystals to suspensions of fura 2 loaded neutrophils, neutrophils were treated with $0.02 \%$ Triton $\mathrm{X}-100$ to saturate fura 2 with calcium. The fluorescence intensities (at $340 \mathrm{~nm}$ excitation) were monitored. Crystals were added in incremental amounts and any subsequent increases in fluorescent intensity were treated as scatter intensities $\left(\mathrm{F}_{\text {scat }}\right)$.

\section{DETERMINATION OF CRYSTAL-NEUTROPHIL}

ASSOCIATION

Diphenylhexatriene labelled neutrophils $(1.5 \mathrm{ml})$ at $5 \times 10^{6}$ cells $/ \mathrm{ml}$ were added to a fluorescence cuvette at $37^{\circ} \mathrm{C}$ and the emission spectrum recorded from 400 to $475 \mathrm{~nm}$ using $355 \mathrm{~nm}$ excitation and a Shimadzu RF 540 spectrofluorophotometer. Crystals of CPPD $(75 \mathrm{mg}$ ) were added and stirred for 10 minutes at $37^{\circ} \mathrm{C}$ using a stir bar accessory (Hellma Canada). The stirrer was switched off and the contents of the cuvette allowed to sediment under gravity for two minutes. The emission spectra of the supernatants were recorded. The percentage neutrophil association with crystals was determined using the following equation

Neutrophil association $(\%)=\left(1-F_{c} / F_{0}\right) \times 100$

where $F_{o}$ is the fluorescence emission intensity at $428 \mathrm{~nm}$ for diphenylhexatriene loaded neutrophils alone (crystals absent) and $F_{c}$ is the fluorescence emission intensity at $428 \mathrm{~nm}$ of supernatants after gravity sedimentation of crystal-neutrophil suspensions.

\section{CHEMILUMINESCENCE}

Cells $\left(5 \times 10^{6}\right), 1 \mu \mathrm{M}$ luminol (dissolved in dimethylsulphoxide) and $50 \mathrm{mg}$ CPPD crystals were mixed and chemiluminescence monitored using an LKB Luminometer (Model 1250) at $37^{\circ} \mathrm{C}$ with shaking immediately before measurements. Control tubes contained cells and luminol (crystals absent).

\section{SUPEROXIDE ANION GENERATION}

Eppendorf tubes containing CPPD crystals (final concentration, $50 \mathrm{mg} / \mathrm{ml}$ ), $1 \mathrm{mg} / \mathrm{ml}$ ferricytochrome $c$ (horse heart type 3 ; Sigma), and cells $\left(5 \times 10^{6} / \mathrm{ml}\right)$ were incubated at $37^{\circ} \mathrm{C}$ by tumbling end over end at $100 \mathrm{rev} / \mathrm{min}$. Identical tubes also containing $600 \mathrm{U} / \mathrm{ml}$ 
superoxide dismutase (Sigma) were tumbled at $37^{\circ} \mathrm{C}$. At given time intervals the tubes were removed, centrifuged at $10000 \mathrm{~g}$ for 10 seconds and the supernatant removed for immediate spectrophotometric assay at $550 \mathrm{~nm}$. The concentration of superoxide anion in the supernatant was calculated using an extinction coefficient of 0.0211 for ferricytochrome $c$.

NEUTROPHIL DEGRANULATION

Cells $\left(5 \times 10^{6} / \mathrm{ml}\right)$ and CPPD crystals $\left(50 \mathrm{mg} / \mathrm{ml}\right.$ ) were incubated at $37^{\circ} \mathrm{C}$ by tumbling end over end at $100 \mathrm{rev} / \mathrm{min}$ in microfuge tubes and at given time intervals the tubes were removed, centrifuged in a microfuge for 10 seconds, and $0.4 \mathrm{ml}$ supernatant frozen at $-20^{\circ} \mathrm{C}$ for later assay. Lysozyme was measured by adjusting the absorbance of a $2.5 \mathrm{ml}$ Micrococcus lysodeikticus (Sigma) suspension $(0.1 \mathrm{mg} / \mathrm{ml}$ in $0.65 \mathrm{M}$ potassium phosphate buffer, $\mathrm{pH} 6 \cdot 2$ ) to $0 \cdot 7$, adding $100 \mu \mathrm{l}$ supernatant, and monitoring the decrease in absorbance with time. Lysozyme standards (chicken egg white; Sigma) in the 0-2000 U/ml range were prepared and a standard curve obtained. Myeloperoxidase activity was determined by monitoring the change in absorbance per minute $\left(\Delta \mathrm{A}_{450}\right)$ of $0.89 \mathrm{ml} 3.2 \mathrm{mM}$ $o$-dianisidine (Sigma) solution in $0.1 \mathrm{M}$ citrate buffer, $\mathrm{pH} 5 \cdot 5$, to which had been added $10 \mu \mathrm{l}$ $10 \mathrm{mM}$ hydrogen peroxide, $50 \mu 1 \mathrm{1} \%$ Triton $\mathrm{X}-100$, and $50 \mu \mathrm{l}$ supernatant. Myeloperoxidase activity was calculated from the following relationship

Dianisidine oxidation $(\mathrm{nmol} / \mathrm{min})=50 \Delta \mathrm{A}_{450}$

Supernatants from these degranulation experiments were also assayed for lactate dehydrogenase levels as previously described. ${ }^{3}$

\section{LEUKOTRIENE GENERATION}

Cells $\left(3 \times 10^{7} / \mathrm{ml}\right)$ and CPPD $(100 \mathrm{mg} / \mathrm{ml})$ were tumbled at $37^{\circ} \mathrm{C}$ as previously described for 30 minutes, centrifuged at $10000 \mathrm{~g}$ for 10 seconds and the supernatants collected for leukotriene extraction. ${ }^{17}$ Briefly, $1.5 \mathrm{ml}$ supernatant was added to conditioned $\mathrm{C} 18$ extraction cartridges (Baker) and leukotrienes eluted with $5 \mathrm{ml}$ methanol, evaporated to dryness under nitrogen and reconstituted in $200 \mu \mathrm{l}$ methanol. Leukotrienes were measured by reversed phase high performance liquid chromatography (HPLC) using ultraviolet detection at $280 \mathrm{~nm}$ by the method of Steffenrud and Salari. ${ }^{18}$ The HPLC system consisted of a Beckman Model 110A pump, a Model 210 sample injection valve fitted with a $20 \mu l$ loop, a Beckman Model 160 ultraviolet detector, and a Shimadzu C-R3 integrator. The column was an ODS C18 silica column (Beckman) and the mobile phase was methanol/water, $7: 3 \mathrm{v} / \mathrm{v}$, containing $0 \cdot 1 \%$ heptafluorobutyric acid adjusted to $\mathrm{pH} 3.0$ with triethylamine at a flow rate of $1 \mathrm{ml} / \mathrm{min}$. The internal standard, was added to the sample before extraction.
PRECOATING CRYSTALS WITH PROTEINS

Crystals were incubated by tumbling with $50 \%$ normal human serum, 50\% plasma (freshly collected using heparin anticoagulant) or $6 \mathrm{mg} / \mathrm{ml} \mathrm{IgG} \mathrm{(human;} \mathrm{Sigma)} \mathrm{at} 37^{\circ} \mathrm{C}$ for 30 minutes. Zymosan $(2 \mathrm{mg} / \mathrm{ml})$ was also incubated with $50 \%$ serum. Following centrifugation at $10000 \mathrm{~g}$ for 10 seconds, the crystal pellets were washed in HBSS and recentrifuged.

IgG BINDING TO CRYSTALS

Crystals of CPPD $(6.25 \mathrm{mg})$ that had been precoated with plasma or IgG were boiled for 1.5 minutes in $100 \mu \mathrm{l} 2 \%$ sodium dodecyl sulphate (SDS) containing $0.1 \mathrm{M}$ dithiothreitol. The supernatant $(20 \mu \mathrm{l})$ was analysed by polyacrylamide gel electrophoresis (PAGE) using a $7 \cdot 5 \%$ gel in a Mini-protean 2 dual slab electrophoresis system (Bio Rad, Richmond, CA, USA). Bands were visualised by Coomassie blue staining. Crystals of CPPD $(50 \mathrm{mg} / \mathrm{ml})$ were tumbled at $37^{\circ} \mathrm{C}$ for 30 minutes with fluorescein isothiocyanate conjugated human IgG $(6 \mathrm{mg} / \mathrm{ml})$ (Sigma). After centrifugation at $10000 \mathrm{~g}$ for 10 seconds, the crystal pellets were washed twice in excess HBSS and recentrifuged. The crystal pellets were then vortexed and boiled in $2 \%$ SDS containing $0 \cdot 1 \mathrm{M}$ dithiothreitol to release any bound fluorescein labelled IgG. The fluorescein labelled IgG was then measured using fluorescence spectroscopy at $480 \mathrm{~nm}$ excitation, $520 \mathrm{~nm}$ emission (Shimadzu spectrofluorometer).

ADSORPTION OF ENZYMES AND LEUKOTRIENES BY CPPD CRYSTALS

Supernatants from degranulation studies were collected, $50 \mu \mathrm{l}$ retained for enzyme analysis, and the remaining portion incubated with uncoated or plasma coated CPPD crystals $(50 \mathrm{mg} / \mathrm{ml})$ at $37^{\circ} \mathrm{C}$ for 10 minutes. After centrifugation at $10000 \mathrm{~g}$ for 10 seconds, supernatants were assayed for myeloperoxidase or lysozyme and the results compared with myeloperoxidase or lysozyme assay values from control $(50 \mu \mathrm{l})$ samples. Leukotriene adsorption was carried out by incubating CPPD crystals $(50 \mathrm{mg} / \mathrm{ml})$ with a solution of $1 \mathrm{mg} / \mathrm{ml}$ each of leukotriene $B_{4}$ $\left(\mathrm{LTB}_{4}\right)$, the $\mathrm{LTB}_{4}$ omega oxidised metabolite $\mathrm{LTB}_{4}-\mathrm{OH}$, and prostaglandin $\mathrm{B}_{2}$ for 10 minutes at $37^{\circ} \mathrm{C}$.

\section{Results}

Concentrations of neutrophils and crystals found to produce significant and reproducible levels of neutrophil activation and responses were $5 \times 10^{6}$ cells $/ \mathrm{ml}$ and $50 \mathrm{mg} / \mathrm{ml} \mathrm{CPPD}$ crystals. These concentrations were used in all studies except for leukotriene determinations where higher cell and crystal concentrations were needed to produce sufficient amounts of leukotrienes for measurement.

Figures 2, 4, 5, and 6 each show representative time course data for one experiment. 
Table 1 shows a statistical treatment of pooled data from several time course experiments (between three and 12 experiments).

CRYSTAL-NEUTROPHIL ASSOCIATION

These experiments were adapted from previously published methods for measuring the binding or association of MSUM to platelets ${ }^{14}$ and erythrocytes. ${ }^{19}$ The studies were based on monitoring the decrease in fluorescence intensity of supernatants when diphenylhexatriene labelled neutrophils were mixed with crystals and allowed to settle under gravity. This process largely sedimented crystals and neutrophils associated with crystals but not 'free' neutrophils, which therefore remained in the supernatant. The 'free' neutrophils in the supernatant could be determined by reading the fluorescence intensity of the supernatant, this intensity being the total diphenylhexatriene emission from the neutrophils in the supernatant. A series of dilutions of a neutrophil suspension from $5 \times 10^{6}$ to $5 \times 10^{5}$ cells $/ \mathrm{ml}$ showed a linear decrease in fluorescence intensity at $428 \mathrm{~nm}$ with a correlation coefficient of 0.9997 .

This so called association of neutrophils and crystals could include neutrophils with crystals bound to the plasma membrane, or neutrophils with internalised or phagocytosed crystals, or both. Preliminary experiments to optimise the crystal concentration at a cell concentration of $5 \times 10^{6}$ cells $/ \mathrm{ml}$ showed that the percent association of crystals with neutrophils was 10 , 17,27 , and $30 \%$ at crystal concentrations of $4 \cdot 5,9,18$, and $27 \mathrm{mg} / \mathrm{ml}$. At a crystal and cell concentration of $50 \mathrm{mg} / \mathrm{ml}$ and $5 \times 10^{6} \mathrm{cells} / \mathrm{ml}$, the percentage association of crystals with neutrophils was $53(11) \%$. Figure 1 shows the effect of protein precoating of CPPD on the percentage neutrophil association at $50 \mathrm{mg} / \mathrm{ml}$ CPPD crystals. Precoating CPPD crystals with plasma, serum, or serum heated at $56^{\circ} \mathrm{C}$ had no effect on the percentage neutrophil association. IgG coated CPPD crystals significantly increased the percentage neutrophil

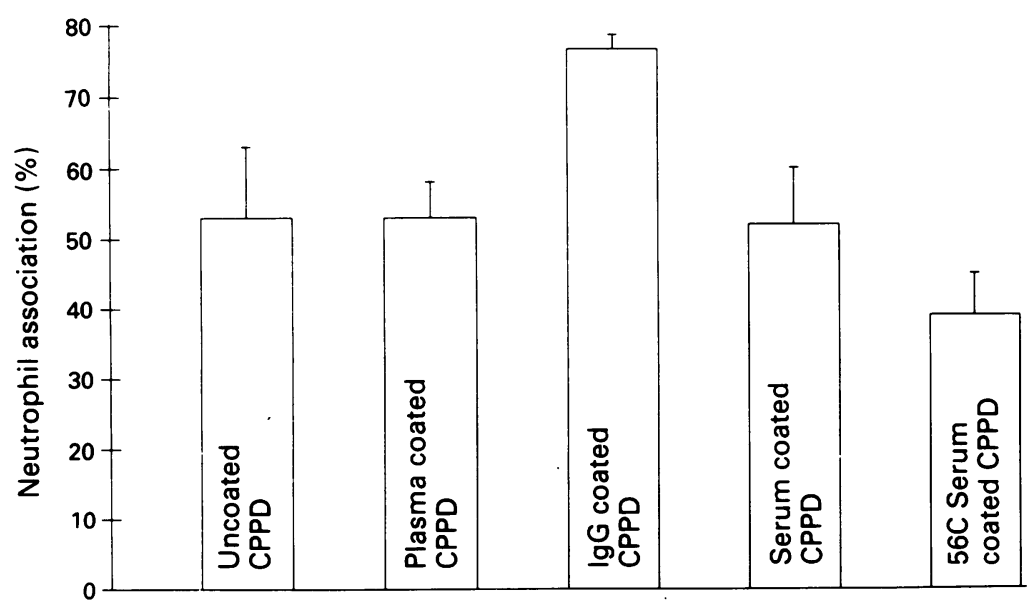

Figure 1 Effect of precoating calcium pyrophosphate dihydrate (CPPD) crystals with plasma, IgG, serum, and complement depleted serum on diphenylhexatriene labelled neutrophil association with crystals at $37^{\circ} \mathrm{C}$. Crystal concentration, $50 \mathrm{mg} / \mathrm{ml}$; neutrophil concentration, $5 \times 10^{6}$ cells $/ \mathrm{ml}$. association (78 (2)\%) compared with uncoated CPPD crystals $(\mathrm{p}<0 \cdot 01)$.

CHEMILUMINESCENCE

The chemiluminescent response of neutrophils to uncoated CPPD crystals increased significantly as the crystal concentration was increased, the peak response at $10 \mathrm{mg} / \mathrm{ml}$ CPPD crystals being only approximately $20 \%$ of the peak response at $50 \mathrm{mg} / \mathrm{ml}$. Crystal concentrations greater than $50 \mathrm{mg} / \mathrm{ml}$ produced decreased chemiluminescence, probably owing to interference of the high concentration of suspended material with light emission. The chemiluminescent responses of neutrophils stimulated by plasma, serum, and heated serum precoated CPPD crystals were faster and more extensive than neutrophils stimulated by $50 \mathrm{mg} / \mathrm{ml}$ uncoated CPPD crystals (fig 2). Similar results were obtained for IgG coated CPPD crystals. Maximum chemiluminescent response was reached in about three to five minutes for uncoated CPPD crystals and in about two to three minutes for plasma, serum, heated serum, and IgG coated CPPD.

Maximum neutrophil chemiluminescent responses to all protein coated CPPD crystal samples were significantly higher than maximum chemiluminescent responses to uncoated CPPD crystals $(p<0.01)$. Table 1 gives the increases in neutrophil response to protein coated relative to uncoated CPPD crystals. Crystals of CPPD coated with serum heated at $56^{\circ} \mathrm{C}$ to deplete complement induced a lower chemiluminescence response than serum coated CPPD crystals. Similar results were obtained with zymosan coated with serum or complement depleted serum.

CYTOSOLIC FREE CALCIUM, $\left[\mathrm{Ca}^{2+}\right]_{\mathrm{i}}$

The value of $\left[\mathrm{Ca}^{2+}\right]_{\mathrm{i}}$ increased above resting (control) neutrophil levels when neutrophils were stimulated by uncoated CPPD crystals, reaching a maximum value at four minutes. $\left[\mathrm{Ca}^{2+}\right]_{\mathrm{i}}$ at crystal concentrations of $5,10,20$, and $30 \mathrm{mg} / \mathrm{ml}$ were approximately 60,120 , 150 , and 200 nmoles respectively. $\left[\mathrm{Ca}^{2+}\right]_{\mathrm{i}}$ at $50 \mathrm{mg} / \mathrm{ml}$ was about $320 \mathrm{nmoles}$. At CPPD crystal concentrations greater than $50 \mathrm{mg} / \mathrm{ml}$ fluorescence emission values were decreased. Figure 3 and table 1 show that CPPD crystals coated with serum, complement depleted serum, plasma or IgG all induced greater increases in $\left[\mathrm{Ca}^{2+}\right]_{\text {i }}$ above resting levels than uncoated CPPD. All $\left[\mathrm{Ca}^{2+}\right]_{\mathrm{i}}$ increases due to protein coated crystals were significantly higher than $\left[\mathrm{Ca}^{2+}\right]_{\mathrm{i}}$ increases due to uncoated crystals $(\mathrm{p}<0.01)$.

SUPEROXIDE ANION GENERATION

Figure 4 shows the time course of superoxide dismutase inhibitable superoxide anion generation by neutrophils stimulated by plasma, serum, and IgG coated CPPD and uncoated CPPD crystals. All protein coated crystals resulted in a significant enhancement $(p<0.01)$ 


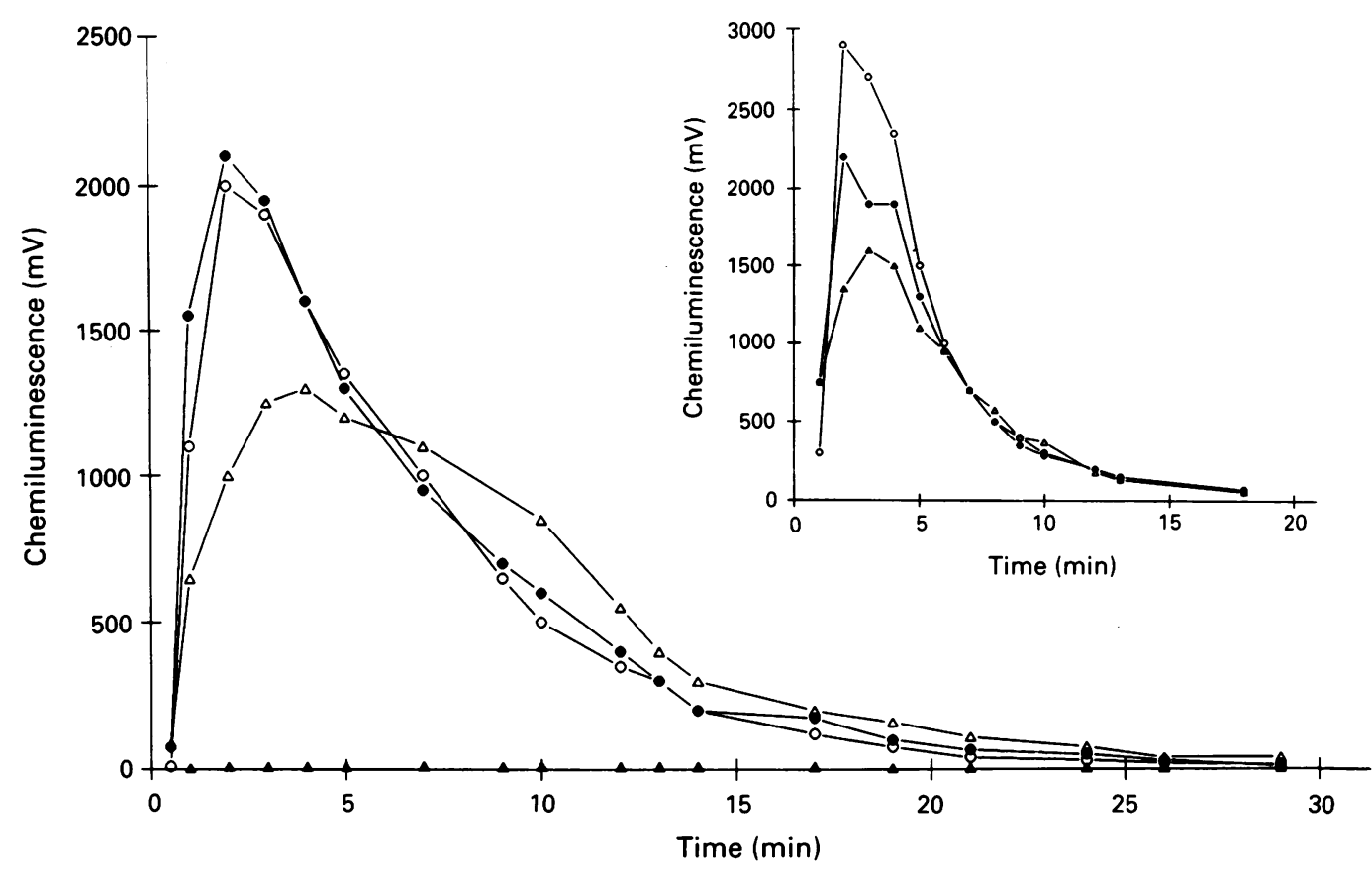

Figure 2 Time course of luminol enhanced chemiluminescent response of neutrophils $\left(5 \times 10^{6}\right.$ cells $\left./ \mathrm{ml}\right)$ stimulated by

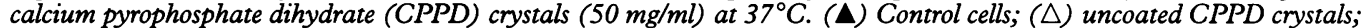
(O) serum coated CPPD crystals; and (O) plasma coated CPPD crystals. Inset: ( $\mathbf{\Delta}$ ) uncoated CPPD; (O) complement depleted serum coated CPPD; and $(O)$ serum coated $C P P D$.

Table 1 Percentage increases in neutrophil responses at $37^{\circ} \mathrm{C}$ to protein coated calcium pyrophosphate dihydrate (CPPD) crystals relative to uncoated CPPD crystal (CPPD, $50 \mathrm{mg} / \mathrm{ml}$; neutrophils, $5 \times 10^{6} / \mathrm{ml}$ )

\begin{tabular}{|c|c|c|c|c|}
\hline \multirow[t]{2}{*}{ Neutrophil response } & \multicolumn{4}{|c|}{ Percentage increase in response to protein coated $C P P D$ relative to uncoated $C P P D^{*}$} \\
\hline & Plasma coated & Serum coated & $\begin{array}{l}\text { Coated with serum } \\
\text { treated at } 56^{\circ} \mathrm{C}\end{array}$ & IgG coated \\
\hline Chemiluminescence & $66(29)(n=9)$ & $\begin{array}{l}61(23)(n=9) \\
66(16)(n=8)\end{array}$ & $22(12)(n=8)$ & $61(26)(n=10)$ \\
\hline Calcium mobilisation $\dagger$ & $82(56)(n=12)$ & $\begin{array}{r}91(42)(n=12) \\
117(31)(n=10)\end{array}$ & $69(43)(n=10)$ & $47(24)(n=5)$ \\
\hline $\begin{array}{l}\text { Superoxide anion generated } \neq \\
\text { Degranulation: lysozyme release } \$\end{array}$ & $123(51)(n=4)$ & $\begin{array}{c}108(45)(n=7) \\
55(14)(n=4)\end{array}$ & $\begin{array}{l}53(34)(n=4) \\
21(5)(n=3)\end{array}$ & $\begin{array}{r}116(58)(\mathrm{n}=4) \\
91(17)(\mathrm{n}=4)\end{array}$ \\
\hline
\end{tabular}

$\star$ Mean (SD) percentage increase in response $=100\left[\left(R_{p}-R_{c}\right)-\left(R_{u n}-R_{c}\right) /\left(R_{u n}-R_{c}\right)\right]$ where $R_{p}=$ neutrophil response to protein coate CPPD, $R_{c}=$ control neutrophil response (CPPD absent) and $R_{u n}=$ neutrophil response to uncoated CPPD.

tResponse measured at maximum.

$\dashv$ Response measured at maximum.

§Response measured at 17 minutes.

of superoxide generation by neutrophils compared with uncoated crystals (measured at 10 minutes). Table 1 gives the values of the percentage increases (at 10 minutes). To verify these results obtained with the ferricytochrome $c$ reduction assay, we used the nitro blue tetrazolium assay ${ }^{20}$ to measure superoxide generation in a single time course experiment.

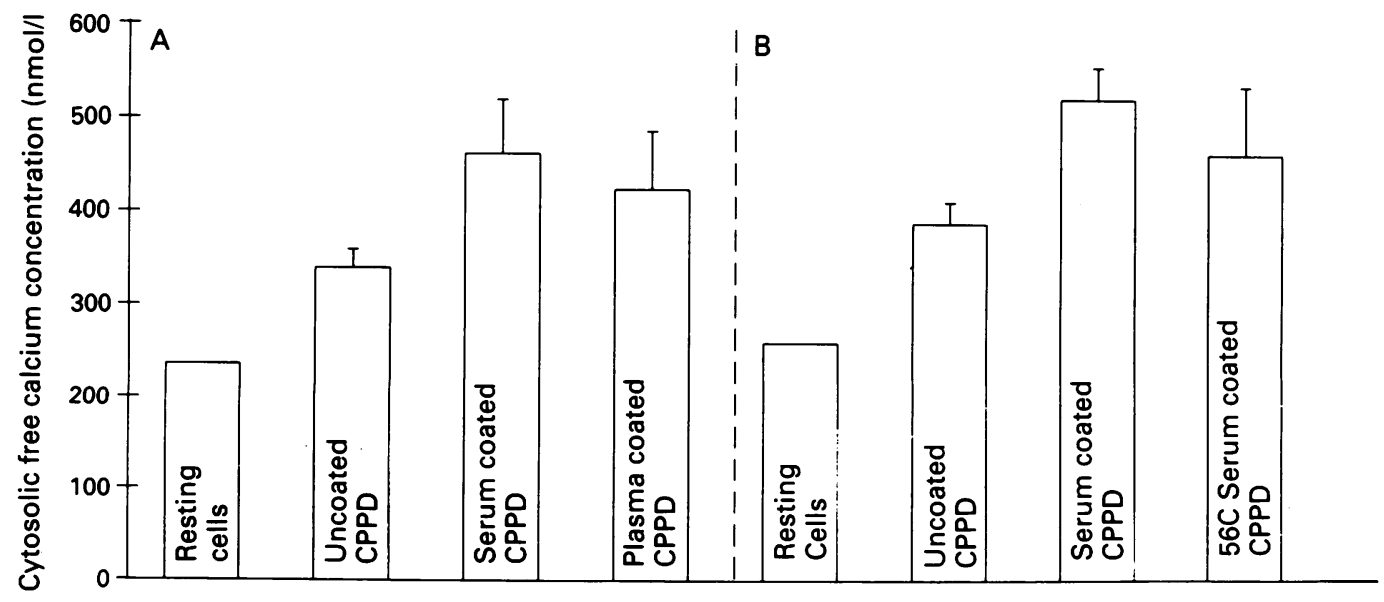

Figure 3 Changes in neutrophil $\left(5 \times 10^{6} \mathrm{cells} / \mathrm{ml}\right)$ cytosolic free calcium concentrations after four minutes' incubation with calcium pyrophosphate dihydrate (CPPD) crystals $(50 \mathrm{mg} / \mathrm{ml})$ at $37^{\circ} \mathrm{C}$. (A) Effect of serum or plasma coating of CPPD crystals. (B) Effect of serum or heat treated (complement depleted) serum coating of CPPD. 


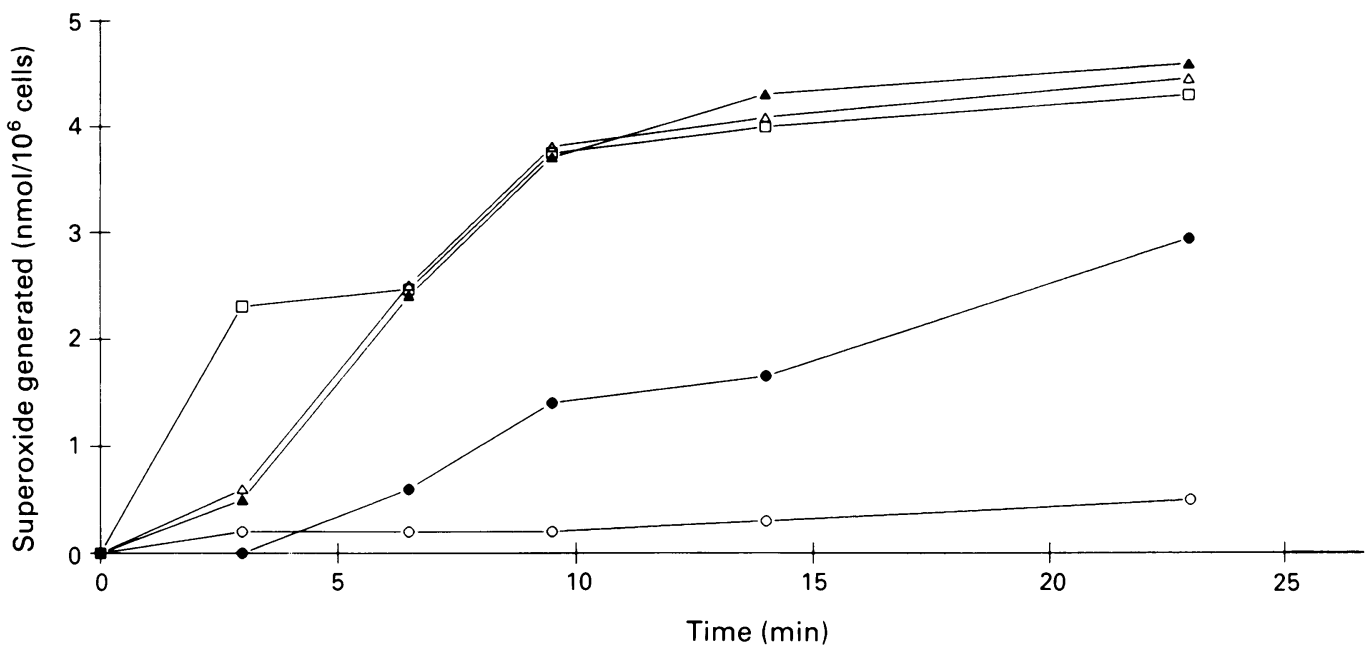

Figure 4 Time course of superoxide anion release from neutrophils $\left(5 \times 10^{6} \mathrm{cells} / \mathrm{ml}\right)$ stimulated by calcium pyrophosphate dihydrate (CPPD) crystals $(50 \mathrm{mg} / \mathrm{ml})$ at $37^{\circ} \mathrm{C}$. (O) Control cells; (O) uncoated CPPD crystals; ( $\left.\square\right)$ plasma coated $C P P D$ crystals; $(\triangle)$ IgG coated CPPD crystals, and $(\mathbf{\Delta})$ serum coated CPPD crystals.

A similar time course profile of superoxide generation to that in fig 4 was produced by uncoated CPPD crystals, and plasma coated CPPD crystals induced significantly greater levels of superoxide by neutrophils.

NEUTROPHIL DEGRANULATION

Figure 5 shows the time course of CPPD crystal induced neutrophil degranulation, as monitored by extracellular lysozyme concentration. Coating CPPD crystals with plasma, serum, complement depleted serum, or IgG produced significantly higher levels of lysozyme release than uncoated CPPD $(p<0.01)$ (fig 5 and table 1). Table 1 gives the values of the percentage increases of lysozyme release measured at 17 minutes due to protein coated crystals relative to uncoated crystals. Myeloperoxidase release from neutrophils may be measured by monitoring the rate of oxidation of dianisidine and hence the time course of CPPD induced myeloperoxidase release from neutrophils is given in fig 6 . In a single time course experiment serum and IgG coating of CPPD crystals produced a greater release of myeloperoxidase from neutrophils than uncoated CPPD.

Supernatants from degranulation experiments were assayed for lactate dehydrogenase release. Over the $40-50 \mathrm{~min}$ period of incubation of neutrophils and crystals in these studies, we found no significant release of lactate dehydrogenase from neutrophils over controls, indicating that myeloperoxidase and lysozyme release was not simply a result of neutrophil cytolysis.

\section{LEUKOTRIENE RELEASE}

Significant amounts of the $\mathrm{LTB}_{4}$ omega oxidised metabolite, $\mathrm{LTB}_{4}-\mathrm{OH}$, were synthesised by neutrophils in response to stimulation by CPPD crystals for 30 minutes (table 2). Neutrophils were also incubated

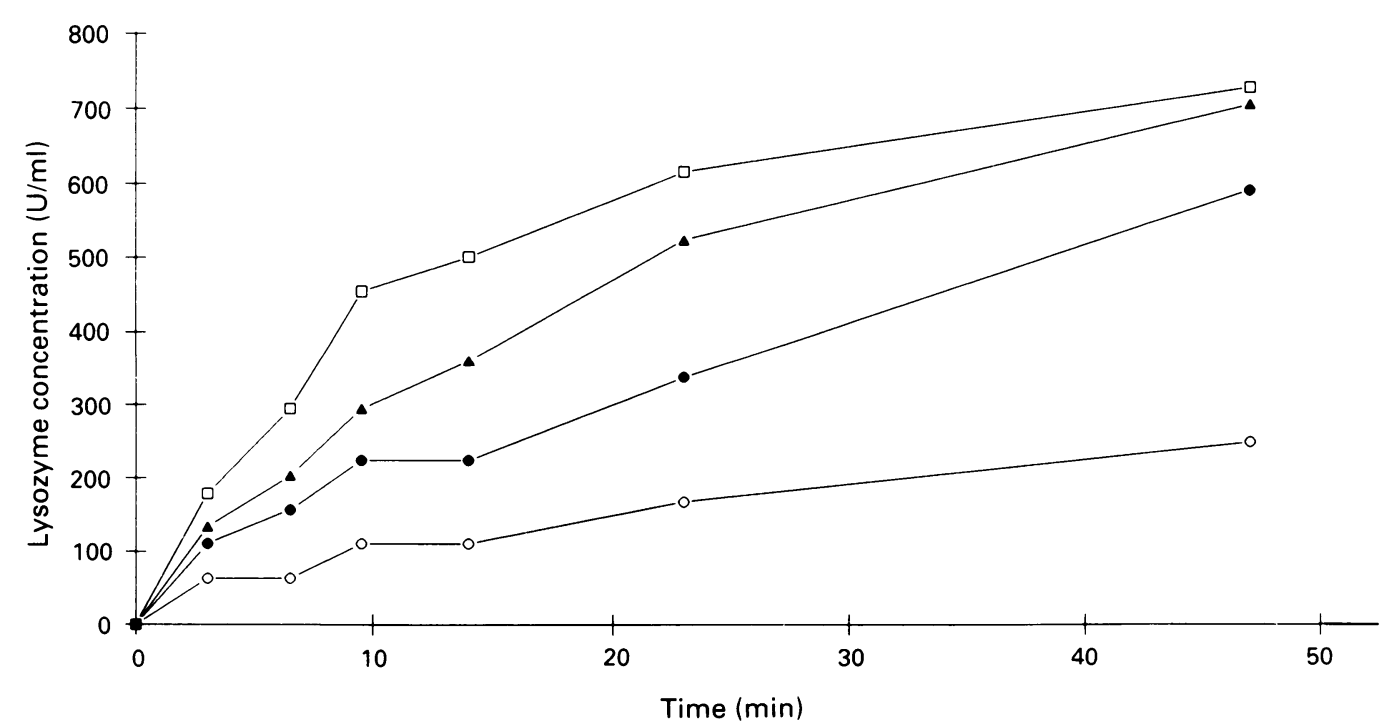

Figure 5 Time course of neutrophil degranulation as measured by lysozyme release from neutrophils $\left(5 \times 10^{6} \mathrm{cells} / \mathrm{ml}\right)$ stimulated by calcium pyrophosphate dihydrate (CPPD) crystals $(50 \mathrm{mg} / \mathrm{ml})$ at $37^{\circ} \mathrm{C}$. (O) Control cells; (O) uncoated CPPD crystals; $(\mathbf{\Lambda})$ serum coated CPPD crystals, and $(\square)$ plasma coated CPPD crystals. 


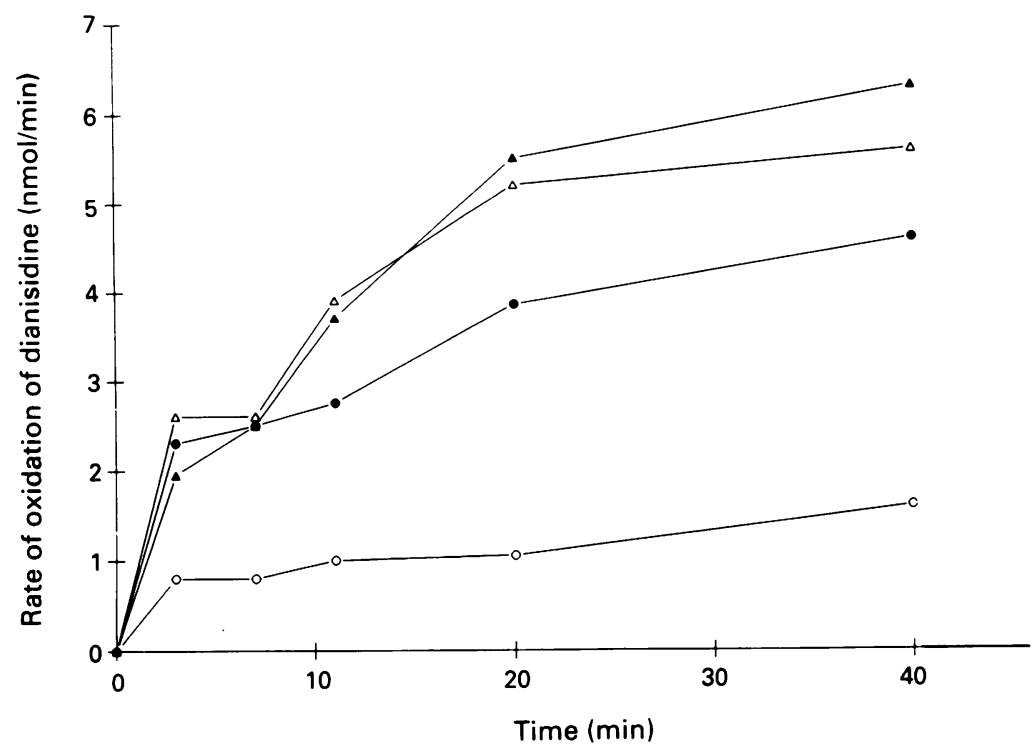

Figure 6 Time course of neutrophil degranulation as measured by myeloperoxidase release from neutrophils $\left(5 \times 10^{6} \mathrm{cells} / \mathrm{ml}\right)$ (myeloperoxidase activity expressed as the rate of oxidation of dianisidine in nmol/min) stimulated by calcium pyrophosphate dihydrate (CPPD) crystals $(50 \mathrm{mg} / \mathrm{ml})$ at $37^{\circ} \mathrm{C}$. (O) Control cells; (O) uncoated CPPD crystals, $(\triangle)$ IgG coated CPPD crystals; and ( $\mathbf{\Delta}$ ) serum coated CPPD crystals.

Table 2 Recovery of leukotriene $B_{4}$ omega oxidised metabolite ( $\left.L T B_{4}-O H\right)$ from neutrophil incubations $\left(3 \times 10^{7} \mathrm{cells} / \mathrm{ml}\right)$ with uncoated or plasma coated calcium pyrophosphate dihydrate (CPPD) $(100 \mathrm{mg} / \mathrm{ml})$ at $37^{\circ} \mathrm{C}$ for 30 minutes

\begin{tabular}{llc}
\hline Experiment number & \multicolumn{2}{l}{$\mathrm{LTB}_{4} \mathrm{OH}$ recovery (pmoV10 cells) } \\
\cline { 2 - 3 } & Uncoated CPPD & Plasma coated CPPD \\
\hline 1 & $110(20)$ & $90(6)$ \\
2 & $450(78)$ & $570(382)$ \\
3 & $188(53)$ & $428(128)$ \\
\hline
\end{tabular}

with ionomycin, a potent activator of the 5-lipoxygenase pathway, and the amount of $\mathrm{LTB}_{4}-\mathrm{OH}$ recovered was $16 \mathrm{nmol} / 10^{7}$ cells. In two of three experiments there was no significant difference between $\mathrm{LTB}_{4}-\mathrm{OH}$ released from neutrophils stimulated by uncoated versus plasma coated CPPD crystals. Experiment 3 showed that plasma coated CPPD crystals induced significantly increased release of $\mathrm{LTB}_{4}-\mathrm{OH}$ from neutrophils compared with uncoated CPPD crystals.

\section{IgG BINDING TO CRYSTALS}

Sodium dodecylsulphate polyacrylamide gel electrophoresis of an IgG standard ( $4 \mu \mathrm{g}$ total protein was applied to the lane) gave characteristic bands for the heavy and light chains of the dissociated protein. Sodium dodecylsulphate eluates from IgG precoated CPPD crystals gave identical band patterns to the IgG standard. Eluates from plasma precoated CPPD crystals also showed bands which were weaker than those of eluates from IgG precoated crystals at the same molecular weight as the IgG bands. Measurement of binding of FITC IgG conjugate to CPPD crystals showed that at the concentration of IgG used for opsonisation $(6 \mathrm{mg} / \mathrm{ml})$, CPPD crystals $(50 \mathrm{mg} / \mathrm{ml}$ ) bound 47 (8) $\mu \mathrm{g}$ (four samples) of IgG or $0.94 \mu \mathrm{g} \mathrm{IgG/mg} \mathrm{CPPD}$ crystals.
ADSORPTIVE CAPACITY OF CPPD CRYSTALS

We found that neither plasma precoated nor uncoated CPPD crystals adsorbed significant amounts of myeloperoxidase or lysozyme. In addition, there was no significant adsorption of leukotrienes or prostaglandin $B_{2}$ by either uncoated CPPD crystals or plasma precoated CPPD crystals. By way of comparison, uncoated MSUM at $5 \mathrm{mg} / \mathrm{ml}$ adsorbed negligible amounts of lysozyme but 85 (10)\% (three samples) of the myeloperoxidase from identical concentrations of enzymes used in CPPD crystal adsorption experiments.

\section{Discussion}

Previous in vitro studies have shown that the interaction of uncoated triclinic CPPD crystals with neutrophils results in phagocytosis, ${ }^{1}$ increases in $\left[\mathrm{Ca}^{2+}\right]_{\mathrm{i}}{ }^{5}$ and the generation of the superoxide anion. ${ }^{25}$ Neutrophil cytolysis required long incubation times. ${ }^{3}$ Monoclinic crystals of CPPD induced leukotriene synthesis, particularly production of $\mathrm{LTB}_{4}$ and its omega oxidised metabolites. ${ }^{21}$

In this work, under conditions of high levels of crystal-neutrophil association, uncoated CPPD crystals were a potent activator of neutrophils resulting in calcium mobilisation, chemiluminescence, superoxide anion production, non-cytolytic lysosomal enzyme release, and leukotriene synthesis.

Previous studies comparing neutrophil activation by CPPD and MSUM crystals at equivalent concentrations (generally between 3 and $8 \mathrm{mg} / \mathrm{ml}$ ) have shown that CPPD crystals always produced significantly lower neutrophil responses than MSUM crystals. ${ }^{245}$ Our results show that much greater CPPD crystal concentrations $(50 \mathrm{mg} / \mathrm{ml}$ ) were required to produce high levels of neutrophil association and activation. The differences in responses to CPPD and MSUM crystals may be explained at least in part by the difference in surface area of CPPD and MSUM crystals. The long needle shaped habit of the MSUM crystals gives a high surface area to volume ratio compared with the prismatic shape of the CPPD crystal, and specific surface areas of our MSUM samples are generally five to tenfold higher than specific surface areas of our synthetic CPPD triclinic samples. ${ }^{3}$ Hence for a given concentration of MSUM and CPPD, this should lead to a greater surface area of MSUM crystal available for contact with the neutrophil plasma membrane than CPPD crystals.

All neutrophil responses to uncoated and protein coated CPPD crystals have been monitored in the absence of cytochalasin $\mathrm{B}$, a strong inhibitor of phagocytosis commonly used in crystal-neutrophil interaction studies. We feel that the exclusion of cytochalasin $B$ better represents the in vivo CPPD-neutrophil interaction. Cytochalasin $B$ has been reported to inhibit MSUM induced chemiluminescence, ${ }^{14}$ oxygen uptake, ${ }^{20}$ and degranulation ( $\alpha$ mannosidase release).$^{14}$ Cytochalasin B has also caused enhancement and inhibition of the neutrophil superoxide 
anion release induced by a number of particulate and soluble stimuli, which may be related to the nature of the opsonin. ${ }^{22} 23$

The adsorption of IgG to CPPD crystals after precoating the crystals with either IgG or plasma was confirmed. Precoating CPPD crystals with IgG, plasma, or serum enhanced all neutrophil responses with the exception of leukotriene generation, where only one of three experiments showed enhanced $\mathrm{LTB}_{4}-\mathrm{OH}$ recovery after stimulation of neutrophils with plasma coated CPPD crystals. IgG coating of CPPD crystals caused an increase in the association of crystals with neutrophils from $53 \%$ for uncoated CPPD crystals to $78 \%$, but plasma and serum coating of CPPD crystals had no effect on the percentage association of crystal with cells. It is possible that the enhanced neutrophil responses induced by IgG coated CPPD crystals might have been due entirely or in part to the increase in association of IgG coated crystals with neutrophils.

IgG and the complement component $\mathrm{C} 3 \mathrm{~b}$ are well characterised opsonising proteins which activate a number of plasma membrane receptors leading to activation of the neutrophil. Although incubation of CPPD crystals with plasma might have resulted in the adsorption of a number of different protein components from plasma, it appears that there was no masking or interference of the opsonising effects of proteins such as IgG or C3b, or both, by other adsorbed protein species. The effects of precoating CPPD crystals with plasma or serum on crystal induced neutrophil responses were compared owing to the possible adsorption of fibrinogen onto CPPD crystals (MSUM has been shown to adsorb fibrinogen ${ }^{8}$. There was no significant difference between the abilities of either plasma precoated CPPD or serum precoated CPPD crystals to enhance neutrophil responses. It is likely that even if additional proteins are adsorbed onto the crystals from plasma, they do not mask the potentiating effects of IgG or C3b adsorbed on CPPD.

Heating serum at $56^{\circ} \mathrm{C}$ for 30 minutes is a commonly used method to deplete serum of complement. ${ }^{11}$ Heating serum at $63^{\circ} \mathrm{C}$ causes aggregation of $\mathrm{IgG},{ }^{24}$ however, and in precoating crystals with $56^{\circ} \mathrm{C}$ heat treated serum there may have been a decreased adsorption of IgG onto the crystal surface as well as a lack of adsorbed complement species. This might explain the reduced (but not abolished) ability of crystals coated with heat treated serum to enhance neutrophil responses compared with crystals coated with normal serum.

There are two broad categories of agents that are capable of activating neutrophils via receptor and non-receptor mediated pathways. Receptor mediated activation of neutrophils by opsonised particles, such as yeast or zymosan, occurs through specific receptors for $\mathrm{C} 3 \mathrm{~b}$ or the Fc domain of IgG. The signal transduction pathways for $\mathrm{Fc}$ receptor and $\mathrm{C} 3 \mathrm{~b}$ receptor mediated neutrophil responses are the subject of many literature reports. ${ }^{25-28}$ Similarly, the activation pathways for neutrophils stimulated by inflammatory microcrystals, such as MSUM and CPPD crystals, which have no apparent specific receptor on the neutrophil membrane are currently under investigation. ${ }^{52-31}$ It may well be that the pathways leading to crystal induced neutrophil activation may be different for uncoated crystals and for serum/plasma/IgG opsonised crystals. Studies of the neutrophil activation pathways for crystals precoated with plasma, serum, and IgG are in progress.

It has been hypothesised by a number of workers that synovial fluid proteins adsorbed onto crystals are important factors regulating crystal induced inflammation. Synovial fluid is an ultrafiltrate of plasma and proteins are present in low concentrations in normal synovial fluid. ${ }^{32}{ }^{33}$ In inflamatory states, however, the protein concentration becomes increased with increased levels of immunoglobulins, lipoproteins, fibrinogen, and variable levels of complement components. ${ }^{32}{ }^{33}$ This is the first report showing a marked potentiation of all neutrophil responses to IgG, plasma, and serum coated CPPD crystals. We suggest that the adsorption of synovial fluid proteins, including IgG and $\mathrm{C} 3 \mathrm{~b}$, to CPPD crystals in vivo results in the opsonised CPPD crystals becoming a potent neutrophil stimulant and inflammatory agent.

The study was supported by a grant from the Medical Research Council of Canada. The authors thank the Canadian Red Cross, Vancouver for supplying the human blood and the Cross, Vancouver for supplying the human blood and the University of British Columbia for the analysis of the cell suspensions.

1 Schumacher H R, Fishbein P, Phelps P, Tse R, Krauser R. Comparison of sodium urate and calcium pyrophosphate crystal phagocytosis by polymorphonuclear leukocytes. Effect of crystal size and other factors. Arthritis Rheum 1975; 18 (suppl): 783-92.

2 Nagase M, Baker D G, Schumacher H R. Immunoglobulin $\mathrm{G}$ coating on crystals and ceramics enhances polymorphonuclear cell superoxide production: correlation with immunoglobulin G adsorbed. F Rheumatol 1989; 16 971-6.

3 Burt H M, Jackson J K, Rowell J. Calcium pyrophosphate and monosodium urate crystal interactions with neutrophils: effect of crystal size and lipoprotein binding to crystals. F Rheumatol 1989; 16: 809-17.

4 Woolf A D, Dieppe P A. Mediators of crystal-induced inflammation in the joint. Br Med Bull 1987; 43: 429-44.

5 Naccache P H, Grimard M, Roberge C J, et al. Crystalinduced neutrophil activation I. Initiation and modulation of calcium mobilization and superoxide production by microcrystals. Arthritis Rheum 1991; 34: 333-42.

6 Kozin F, McCarty D J. Protein binding to monosodium urate monohydrate and silicon dioxide crystals I. Physica urate monohydrate and silicon dioxide crystals I. Ph.

7 Hasselbacher P. Binding of IgG and complement protein by monosodium urate and other crystals. F Lab Clin Med 1979; 94: 532-41.

8 Terkeltaub R, Tenner A J, Kozin F, Ginsberg M H. Plasm protein binding by monosodium urate crystals. Analysis by two-dimensional gel electrophoresis. Arthritis Rheum 1983; 26: 775-83.

9 Cherian P V, Schumacher H R. Immunochemical and ultrastructural characterization of serum proteins synovial fluid cells from patients with gout. Ultrastruct Pathol 1986; 10: 209-19.

10 Kozin F, Ginsberg M H, Skosey J L. Polymorphonuclear leukocyte responses to monosodium urate crystals: modification by adsorbed serum proteins. $\mathcal{F}$ Rheumatol 1979; 6: 519-26.

11 Abramson S, Hoffstein S T, Weissmann G. Superoxide anion generation by human neutrophils exposed to monoanion generation by human neutrophils exposed to monoment activation. Arthritis Rheum 1982; 25: 174-80.

12 Rosen M S, Baker D G, Schumacher H R, Cherian P V. Products of polymorphonuclear cell injury inhibit IgG Products of polymorphonuclear cell injury inhibit IgG enhancement of monosodium urate-induced

13 Terkeltaub R, Curtiss L K, Tenner A J, Ginsberg M H Lipoproteins containing apoprotein $B$ are a major regulator of neutrophil responses to monosodium urate crystals. F Clin Invest 1984; 73: 1719-30. 
14 Terkeltaub R, Smeltzer D E, Curtiss L K, Ginsberg M H. Low density lipoprotein inhibits the physical interaction of phlogistic crystals and inflammatory cells. Arthritis Rheum 1986; 29: 363-70.

15 Burt H M, Jackson J K. Characterization and membranolytic effects of calcium pyrophosphate dihydrate crystals. $\mathcal{F}$ Rheumatol 1987; 14: 968-73.

16 Grynkiewicz G, Poenie M, Tsien R Y. A new generation of $\mathrm{Ca}^{2+}$ indicators with greatly improved fluorescence properties. F Biol Chem 1985; 260: 3440-50.

17 Steinhilber D, Schmidt K, Eger K, Roth H J. New class of 5-lipoxygenase inhibitors: correlation between inhibition of $\mathrm{LTB}_{4}$ production and chemiluminescence of human polymorphonuclear granulocytes. Pharm Res 1986; 3: polymorph

18 Steffenrud S, Salari H. Reversed-phase ion interaction chromatography of leukotrienes, lipoxins and related compounds. $f$ Chromatogr 1988; 427: 1-7.

19 Burt H M, Jackson J K. Monosodium urate monohydrate crystal induced changes in membrane fluidity: fluorescence polarization study. $₹$ Rheumatol 1988; 15: $1144-51$.

20 Simchowitz L, Atkinson J P, Spilberg I. Stimulation of the respiratory burst in human neutrophils by crystal phagocytosis. Arthritis Rheum 1982; 25: 181-8.

21 Poubelle P E, De Medicis R, Naccache P H. Monosodium urate and calcium pyrophosphate crystals differentially activate the excitation-response coupling sequence of activate the excitation-response coupling sequence of
human neutrophils. Biochem Biophys Res Commun 1987; 149: 649-57.

22 Hed J, Stendahl O. Differences in the ingestion mechanisms of IgG and C3b particles in phagocytosis by neutrophils. Immunology 1982; 45; 727-36.

23 Lucas M, Solano F. Opposite effect of cytochalasin B on agonist-induced respiratory burst in neutrophils and monocytes. Biochem Pharmacol 1991; 42 425-30.

24 Goldstein I M, Roos D, Kaplan H B, Weissmann G. Complement and immunoglobulins stimulate superoxide production by human leukocytes independently of phagocytosis. $\mathcal{F}$ Clin Invest 1975; 56: 1155-63.
25 Blackburn W D, Heck L W. Neutrophil activation by surface bound IgG is via a pertussis toxin insensitive $G$ protein. Biochem Biophys Res Commun 1989; 164: 983-9.

26 Fällman M, Lew D P, Stendahl O, Andersson T. Receptor mediated phagocytosis in human neutrophils is associated with increased formation of inositol phosphates and diacylglycerol. Elevation in cytosolic free calcium and um and 政 886-91.

27 Brunkhorst B A, Lazzari K G, Strohmeier G, Weil G, Simons E R. Calcium changes in immune complex Simons E R. Calcium changes in immune complex
stimulated human neutrophils. Simultaneous measurement of receptor occupancy and activation reveals full ment of receptor occupancy and activation reveals full
population stimulus binding but subpopulation population stimulus binding but subpo
activation. $f$ Biol Chem 1991; 266: 13035-43.

28 Della Bianca V, Grzeskowiak M, Lissandrini D, Rossi F. Source and role of diacylglycerol formed during phagocytosis of opsonized yeast particles and associated respiratory burst in human neutrophils. Biochem Biophys Res Commun 1991; 177: 948-55.

29 Terkeltaub R A, Sklar L A, Mueller H. Neutrophil activation by inflammatory microcrystals of monosodium urate monohydrate utilizes pertussis insensitive and urate monohydrate utilizes pertussis insensitive
sensitive pathways. $\mathcal{F}$ Immunol 1990; 144: 2719-24.

30 Onello E, Traynor-Kaplan A, Sklar L, Terkeltaub R Mechanism of neutrophil activation by an unopsonized Mechanism of neutrophil activation by an unopsonized inflammatory particulate. Monosodium urate crystals induce pertussis toxin-insensitive hydrolysis of phosphatidylinositol 4,5-biphosphate. F Immunol 1991; 146: 4289-94.

31 Bomalaski J S, Baker D G, Brophy L M, Clark M A Monosodium urate crystals stimulate phospholipase $A_{2}$ enzyme activities and the synthesis of a phospholipase $A_{2}$-activating protein. F Immunol 1990; 145: 3391-7.

32 Markowitz H. Synovial fluid proteins. Proteins in body fluids amino acids and tumor markers: diagnostic and clinical aspects. New York, Liss, 1983: 239-53.

33 Revell P A. Examination of synovial fluid. In: Berry C L ed. Current topics in pathology. Bone and joint disease. Vol. 71. Heidelberg: Springer, 1982: 1-24. 